\title{
Push net fishing seems to be responsible for injuries and post fishing mortality in glass eel in the Vilaine estuary (France) in 2007
}

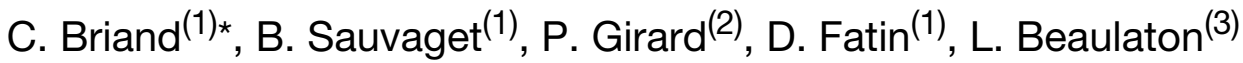 \\ Received December 17, 2010 \\ Revised April 28, 2012 \\ Accepted October 25, 2011
}

\section{ABSTRACT}

Key-words:

Anguilla anguilla, glass eel, push net, mortality, marking

\begin{abstract}
Post fishing mortality of the glass eel was monitored in 2007 in the Vilaine estuary. The mortality of the glass eels varied from 2 to $82 \%$ (mean $42 \%$ ) in the two days following the fishing. The mortality of samples collected by hand nets or from the trapping ladder was null. Alterations of the skin mucus were analyzed by the use of Indigo carmine. The mortality was significantly correlated with body injuries, but not to other environmental factors. The presence of a large injury on the body systematically led to the death of the glass eels, and among these dead glass eels, only $3.5 \%$ had no external injury. These results are discussed, along with the results from other estuaries, with a view to transport glass eels across Europe, with the objective of restoring the eel stock.
\end{abstract}

RÉSUMÉ

Les tamis poussés semblent être responsables de blessures et de mortalités chez la civelle en estuaire de Vilaine (France) en 2007

Mots-clés : Les mortalités de civelles ont été suivies en 2007 dans l'estuaire de la Vilaine. Ces Anguilla anguilla, civelle, tamis, mortalités ont varié de 2 à $82 \%$ (moyenne $42 \%$ ) dans les deux jours suivant la pêche. Les mortalités d'échantillons pêchés à l'aide de tamis à main ou capturés dans la passe à anguilles étaient nulles. Les altérations du mucus de la peau ont été analysées à l'aide de carmin indigo. Les mortalités étaient significativement corrélées aux blessures sur le corps mais pas aux facteurs de l'environnement. La présence d'une importante blessure sur le corps mène systématiquement à la mort des civelles, et au sein des civelles mortes, seules 3,5\% ne portent pas de blessure externe. Ces résultats sont discutés, avec ceux obtenus dans d'autres estuaires, par rapport à l'objectif de transporter des civelles en Europe en vue de restaurer le stock d'anguilles.

(1) Institution d'Aménagement de la Vilaine, Boulevard de Bretagne, 56130 La Roche-Bernard, France

(2) Vétérinaire Consultant en Aquaculture et Environnement Aquatique 04425311 48, patagir@club-internet.fr

(3) Office National de l'Eau et des Milieux Aquatiques, 5 Square Félix Nadar, 94300 Vincennes, laurent.beaulaton@onema.fr

*Corresponding author: cedric.briand@lavilaine.com 


\section{INTRODUCTION}

Three main markets have fostered the development of the glass eel fishing activity on the Atlantic coast of Europe. The export originally turned towards Northern and Eastern Europe for restocking and Mexico for human consumption shifted in the seventies to an export towards Spain, and then progressively towards Japan, then China. This shift was accompanied by a very large increase in prices. The value of glass eel has multiplied a hundred folds since the 1970's (Briand et al., 2008). It has also been accompanied by a slight but continuous increase in effort, mostly related to changes in fishing practices, to compensate for the reduction of abundance, which is now only at $5 \%$ of its 1970's value (ICES, 2008). In the 1960's, in most estuaries of the Atlantic coast, push net fishing (i.e. nets propelled on each side of a boat) replaced the more traditional hand net fishing (Elie and Fontenelle, 1982; Castelnaud et al., 1994, 2000). These push net fisheries sometimes fish at large speed, with the glass eels being pressed in the deepest part of the net. Apart from the increase in fishing effort, push net fishing has two side effects. Firstly, the level of by-catches affects the nursery function of the estuaries (Gascuel, 1985; Robin, 1990; Antunes and Weber, 1996; Sobrino et al., 2005; Gisbert and López, 2008). Secondly, the speed and tow duration conditions are known to induce injuries, which might result in mortality occurring mostly in the days following the fishing, and lesser quality glass eels later sold for aquaculture or restocking purposes. The glass eels are treated by fish dealers to ensure that dying individuals are removed from the holding tanks, and frozen to be later sold to the Spanish food market. A European regulation (Commission of the European communities, 2005) uses the transport of glass eel towards Europe, as one of the possible strategies to rebuild the stock. In this context, the question of glass eel mortality due to fishing practices gains importance. When calculating the net effect of transport on the whole survival, the mortality induced during glass eel fishing and transport has to be accounted for. The objective of this work is to present the results of an experimental monitoring of glass eel mortality after it has been fished. The mortality rate is analyzed in relation to the loss of mucus, which has been brought to light by a new technique: the use of Indigo carmine. The aim of monitoring mortality rates is also to identify if additional factors, linked with the environment (temperature, flow) or the use of a dredge in the estuary, could be responsible for the large waves of mortality observed once every two or three years by the fish dealers.

\section{MATERIALS AND METHODS}

\section{> SITE AND FISHING CONDITIONS}

Since the construction of the Arzal dam, the Vilaine estuary has been reduced from an initial length of $50 \mathrm{~km}$ to $12 \mathrm{~km}$. Close to the dam, the tide ranges $6 \mathrm{~m}$. The mean flow from December to March, the main period for glass eel migration, varies from 100 to $200 \mathrm{~m}^{3} \cdot \mathrm{s}^{-1}$ (2001-2004). The salinity in the estuary ranges from $35 \%$ o to full freshwater conditions during springtime floods.

The glass eel fishing takes place in an area delimited by the dam at the upper end and by a bend marking the enlargement of the estuary $1 \mathrm{~km}$ downstream (Figure 1). The fishing effort is very high with 130 boats licensed for fishing in the Vilaine estuary. Glass eels are fished at night from 6 p.m. to 8 a.m. and from three hours before high tide to one hour after. They are caught with boats equipped with circular nets of $1.2 \mathrm{~m}$ diameter propelled on each side. The nets can be pushed near the surface, but they are often mounted on perches which allow the boats to fish at the bottom near the dam $(8 \mathrm{~m})$. The fishing activity had ceased by the 11th of March 2007. The estuary is dredged from October 15th till March 15th, for tidal coefficients larger than 70 and from one hour before high tide to six hours after. The dredge uses rotating brushes to deepen or maintain navigable channels in the estuary. The dredge operates by putting the mud into suspension and letting it be carried away with tide currents. The location of the dredge was $4.1 \mathrm{~km}$ downstream from the fishing area. 


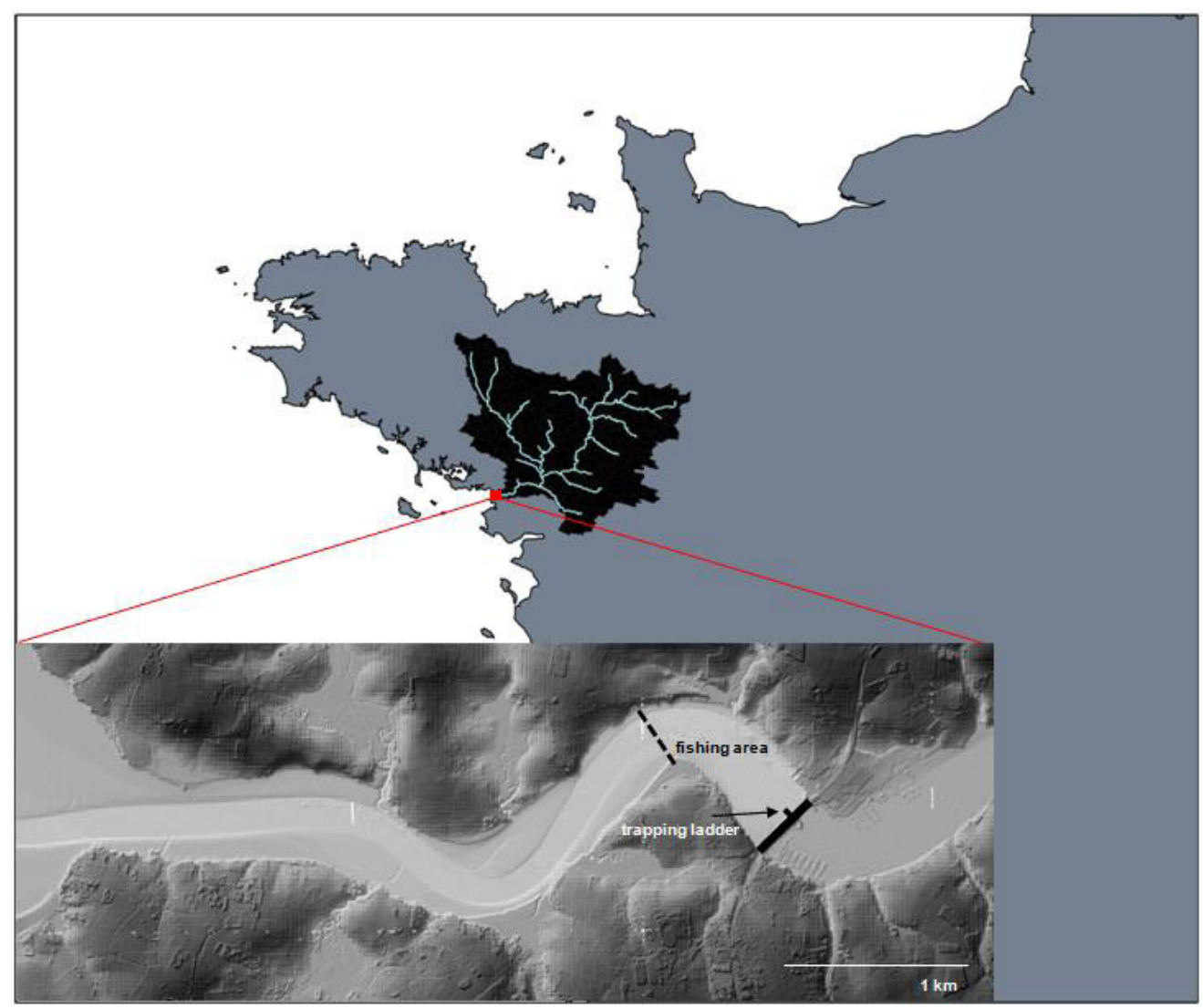

\section{Figure 1}

The Vilaine watershed and a map of the estuary showing the locations of the glass eel fishing area and the trapping ladder.

\section{> EXPERIMENTAL ANALYSIS OF THE EFFECT OF INDIGO CARMINE}

The analysis of skin erosion by Indigo carmine was detected during the screening of various dyes for a marking recapture experiment (in preparatory work for Briand et al., 2005). The duration of $30 \mathrm{~min}$ at a concentration of $0.5 \mathrm{~g} \cdot \mathrm{L}^{-1}$ gave the best results.

Some glass eels collected by the fishery had tails that were colored in blue, hinting that this dye could detect skin injuries. To analyze the effect of the dye, 21 healthy glass eels collected at the trapping ladder were wiped from their mucus, and placed in Indigo carmine $0.5 \mathrm{~g} \cdot \mathrm{L}^{-1}$ during half an hour, and then checked for marks. The same analysis was done on a control sample of 20 glass eels.

\section{> FISHING CONDITION MONITORING}

Twenty five glass eel samples were collected in the Vilaine estuary in 2007 by three methods (Table I).

(1) Fifteen on board of one professional fishing boat. Ten samples came from trips monitored on board, and five additional samples were gathered from other fishing nights where no observer was present. All the samples were collected at regular intervals from 5 th December to 22nd February.

For the fishing monitored on board, the catch per night varied from 0.3 to $3.4 \mathrm{~kg}$ (total $13.5 \mathrm{~kg}$ ). The mean haul duration per trip was 11.2 to $30 \mathrm{~min}$ (mean duration: $17.6 \pm 5.5$ ). The boat speed 
Table I

Description of the 25 glass eels samples collected for the study, * indicates an on board observation. \# no information recorded. Bold values indicates mortalities larger than $30 \%$.

\begin{tabular}{|c|c|c|c|c|c|c|c|c|c|c|}
\hline ते & 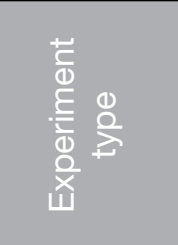 & 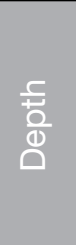 & 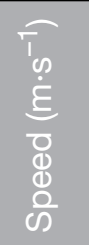 & 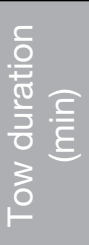 & $\begin{array}{l}\frac{\partial}{2} \\
\frac{9}{3} \\
\frac{0}{0} \\
\frac{0}{0}\end{array}$ & 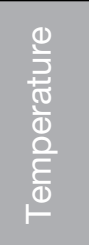 & 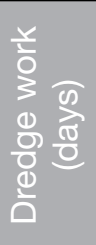 & 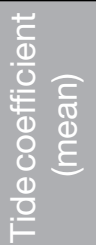 & 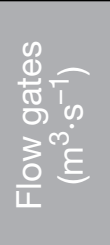 & 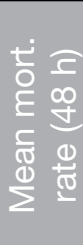 \\
\hline \begin{tabular}{|l|}
$05-d e c-06$ \\
\end{tabular} & Push net ${ }^{\star}$ & 2.5 & 1.39 & 20 & 0.2 & 10.8 & 0.0 & 91 & 276.5 & 0.37 \\
\hline 07-dec-06 & Fishway & & & & & 11.1 & 8.5 & 83.5 & 269.8 & 0 \\
\hline 08-dec-06 & Push net & $\#$ & \# & \# & \# & 11.0 & 5.0 & 76 & 289.5 & 0.25 \\
\hline \begin{tabular}{|l|} 
12-dec-06 \\
\end{tabular} & Push net $^{*}$ & 0.5 & 1.44 & 18 & 0.3 & 9.1 & 0.0 & 41.5 & 354.1 & 0.31 \\
\hline \begin{tabular}{|l|}
$13-d e c-06$ \\
\end{tabular} & Push net & 0.5 & 1.54 & 10 & 2.5 & 9.2 & 0.0 & 37.5 & 344.4 & 0.19 \\
\hline 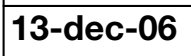 & Fishway & & & & & 9.2 & 0.0 & 37.5 & 344.4 & 0 \\
\hline \begin{tabular}{|l|}
$19-d e c-06$ \\
\end{tabular} & Push net $^{*}$ & 0.5 & 1.59 & 25 & 1.5 & 8.4 & 0.0 & 68.5 & 199.6 & 0.13 \\
\hline 21-dec-06 & Push net & 0.5 & 1.54 & 20 & 2.4 & 7.4 & 8.5 & 79 & 131.8 & 0.14 \\
\hline \begin{tabular}{|l|}
$08-j a n-07$ \\
\end{tabular} & Push net $^{*}$ & 1.2 & 1.54 & 15 & 1.8 & 9.8 & 6.0 & 69 & 232.6 & 0.51 \\
\hline \begin{tabular}{|l|} 
11-jan-07 \\
\end{tabular} & Push net & $\#$ & $\#$ & $\#$ & $\#$ & 10.5 & 0.0 & 43 & 203.7 & 0.29 \\
\hline \begin{tabular}{|l|}
$16-j a n-07$ \\
\end{tabular} & Push net $^{\star}$ & 4.3 & 1.54 & 26 & 3.4 & 10.4 & 0.0 & 36.5 & 175.0 & 0.02 \\
\hline 23-jan-07 & Push net $^{\star}$ & 5.0 & 1.38 & 30 & 1.5 & 10.3 & 6.3 & 91.5 & 187.9 & 0.08 \\
\hline \begin{tabular}{|l|}
$30-j a n-07$ \\
\end{tabular} & Push net* & 5.8 & 1.28 & 30 & 0.6 & 5.6 & 0.0 & 56.5 & 107.0 & 0.60 \\
\hline \begin{tabular}{|c|}
$06-f e b-07$ \\
\end{tabular} & Push net $^{\star}$ & 5.0 & 1.54 & 26 & 2.7 & 9 & 5.3 & 78.5 & 84.9 & 0.14 \\
\hline \begin{tabular}{|l|} 
12-feb-07 \\
\end{tabular} & Push net* & 0.5 & 1.54 & 21 & 0.4 & 10 & 0.0 & 32 & 266.5 & 0.41 \\
\hline \begin{tabular}{|l|}
$20-f e b-07$ \\
\end{tabular} & Push net ${ }^{*}$ & 1.5 & 1.54 & 16 & 1.0 & 10 & 0.0 & 109 & 223.2 & 0.32 \\
\hline 22-feb-07 & Push net & $\#$ & $\#$ & $\#$ & $\#$ & 10 & 8.5 & 90 & 171.8 & 0.19 \\
\hline 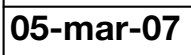 & \multicolumn{2}{|c|}{ Hand net } & & & 0.1 & 12 & 7.0 & 90 & 284.8 & 0 \\
\hline \begin{tabular}{|l|}
$16-m a r-07$ \\
\end{tabular} & \multicolumn{2}{|c|}{ Hand net } & & & 0.1 & 11.2 & 0.0 & 63 & 159 & 0 \\
\hline 22-mar-07 & \multicolumn{2}{|c|}{ Hand net } & & & 0.1 & 9.4 & 0.0 & 104 & 148 & 0.01 \\
\hline 26-mar-07 & \multicolumn{2}{|c|}{ Hand net } & & & 0.1 & 8.9 & 0.0 & 39 & 114 & 0 \\
\hline \begin{tabular}{|l|} 
03-apr-07 \\
\end{tabular} & \multicolumn{2}{|c|}{ Hand net } & & & 0.2 & 11.4 & 0.0 & 87 & 97 & 0 \\
\hline 10-apr-07 & Fishway & & & & & 12.8 & 0.0 & 35.5 & 60 & 0 \\
\hline 17-apr-07 & Fishway & & & & & 15.3 & 0.0 & 109 & 53 & 0 \\
\hline \begin{tabular}{|l|} 
18-apr-07 \\
\end{tabular} & \multicolumn{2}{|c|}{ Hand net } & & & 0.2 & 15.8 & 0.0 & 112 & 54 & 0 \\
\hline
\end{tabular}

varied from 1.29 to $1.59 \mathrm{~m} \cdot \mathrm{s}^{-1}$ (mean speed: $1.48 \pm 0.10$ ). The fishing depth was either at $0.5 \mathrm{~m}$ near the surface or down to 2.5 to $6.5 \mathrm{~m}$ (mean depth: $1.96 \pm 1.87$ ).

The boat, typical of the fishery, was $9 \mathrm{~m}$ long, with a 75 horsepower motor, and equipped with two $1.2 \mathrm{~m}$ diameter circular nets of $2 \mathrm{~mm}$ stretched mesh in the opening of the net and reduced to $1.3 \mathrm{~mm}$ at the bottom end (Briand et al., 2003). The boat's fish tank, full of estuarine water renewed with the boat's pump, was covered by a grid allowing to separate living glass eel from floating remains, by-catch, and dead or dying glass eel (Elie, 1979; Gascuel, 1987). At the end of the fishing activity, samples were collected from that tank, thus excluding a part of the mortality. To observe the fishing conditions and count the glass eels remaining on the grid of 


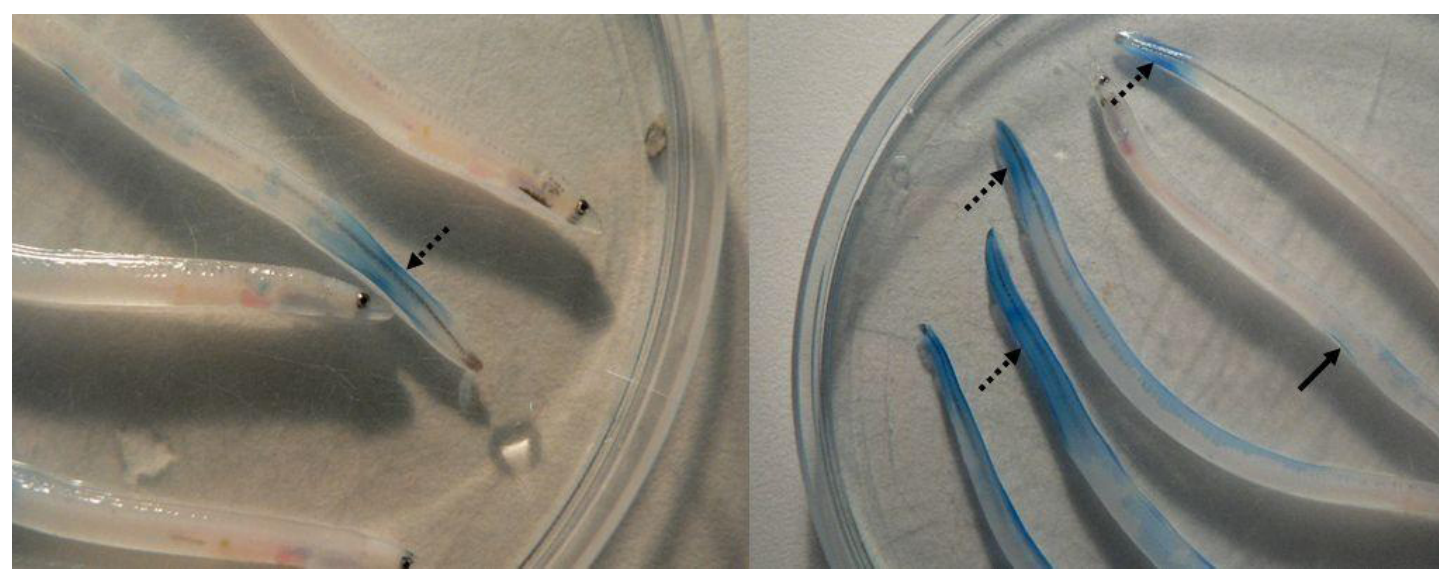

\section{Figure 2}

Result of analyses of glass eels with Indigo carmine (full arrow: mark =1, dotted arrow: mark =2).

the fish tank, an observer was present on board on Monday nights. Some samples were also collected without on board monitoring on Tuesday nights.

(2) Six samplings were done in the sluice with a hand net from 5th March to 18th April, mostly after the fishing season which ended on the 11th March.

The catch per night varied from 60 to $248 \mathrm{~g}$ (total $1.173 \mathrm{~kg}$ ). The duration of a sampling trait was much shorter with hand net than with push net as it varied from 40 to $150 \mathrm{~s}$. The net's speed was about three times lower than when towed from a boat and varied from 0.47 to $0.69 \mathrm{~m} \cdot \mathrm{s}^{-1}$.

(3) Four samples were collected in the holding tank of the trapping ladder from 7th December to 17th April. The ladder is made of two ramps equipped with tuffs of synthetic fibers, wetted by a gentle flow (Briand et al., 2002). At the end of the upper ramp, the glass eels fall into a holding tank. The content of the tank was sorted to separate glass eel from yellow eel, and the glass eel were counted and weighed several times a week.

\section{> MORTALITY MONITORING}

The same procedure was applied to each sample. Dead glass eels were counted and kept for analysis, while the living and dying glass eels were placed in three replicate batches of about 50 glass eels. Each sample was kept in $7.5 \mathrm{~L}$ aquaria filled with estuarine water of salinity varying from 1.5 to $7.5 \%$. The batches were then checked for mortality the next morning several hours after the fishing activity and at regular intervals during the next two days. The total mortality corresponds to the addition of in board mortality, initial mortality back from the fishery and mortality during monitoring.

Dead glass eels and the glass eels still alive at the end of the experiment were treated with Indigo carmine $\left(0.5 \mathrm{~g} \cdot \mathrm{L}^{-1}, 30 \mathrm{~min}\right)$. The location (dorsal, ventral, tail) and the intensity of the mark were recorded. The scale for intensity of ventral and dorsal areas varied from 0 to 2:0 no marks, 1 some marks, 2 marks covering large areas (Figure 2). For the tail, only the classes 0 (absence) and 2 (presence) were used as the narrow range of the location studied prevented from judging the intensity of marking.

\section{> STATISTICAL ANALYSIS}

The location of injuries on the body of glass eels and their independence was analyzed with the vcd package in R (Friendly, 1992; Meyer et al., 2006). The level of injury, conditional to their survival, was assessed using permutation test for conditional independence (Meyer et al., 2006). 
A

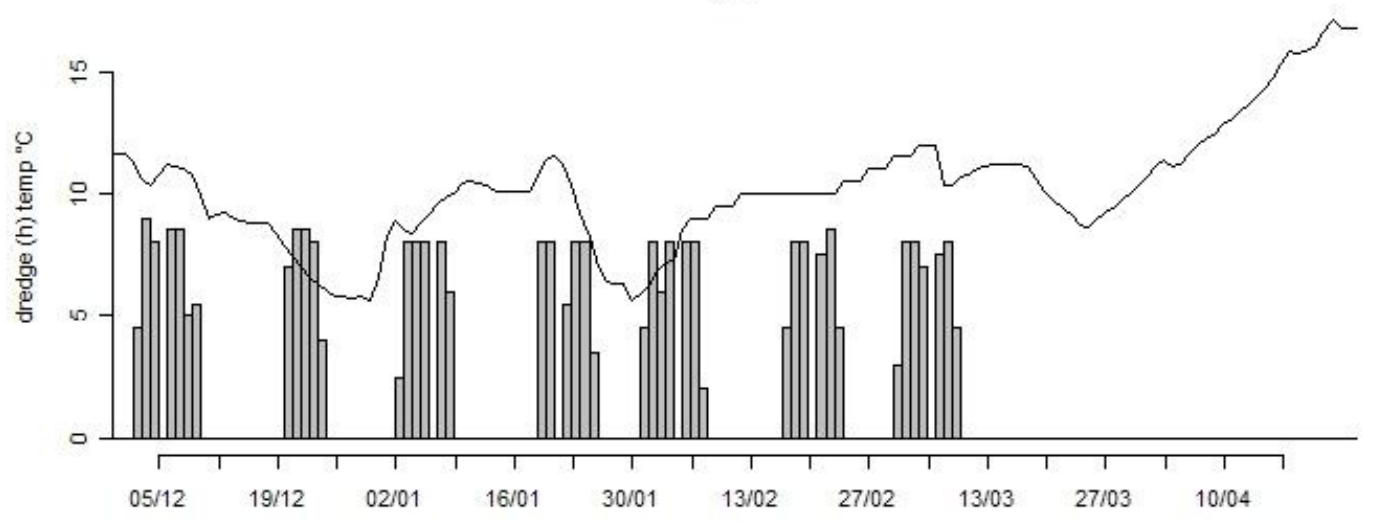

B

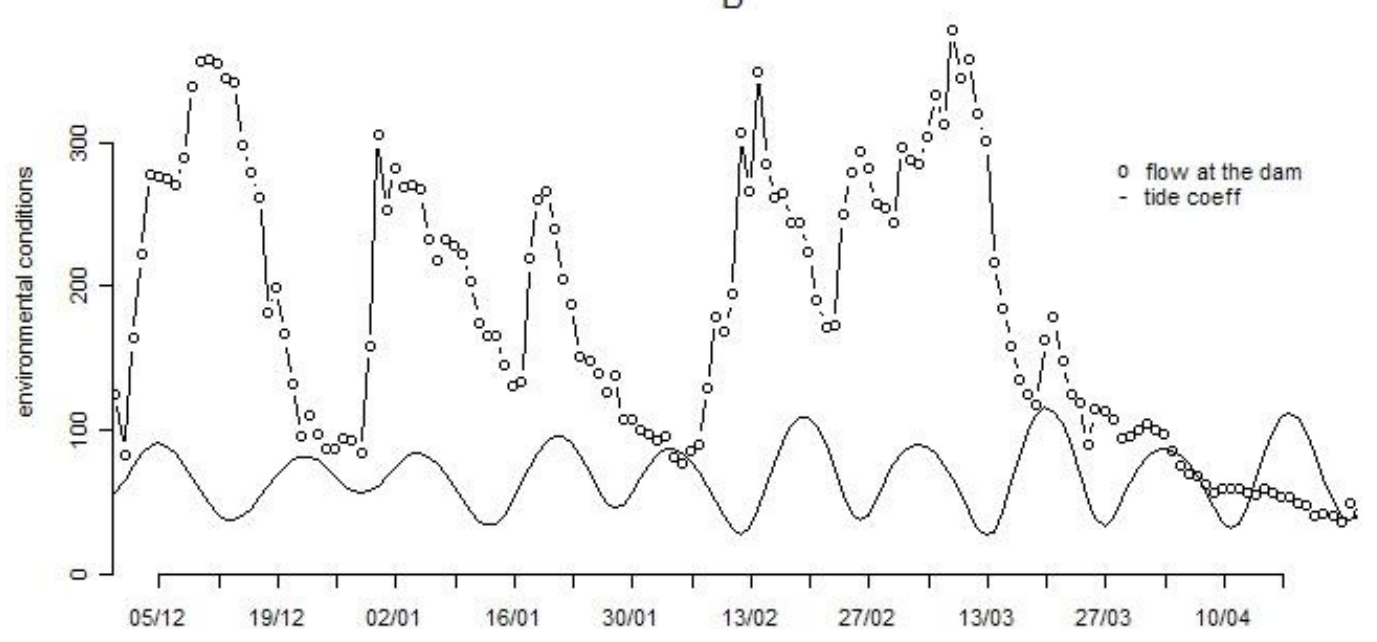

Figure 3

Monitoring of environmental conditions during the study. A. Daily activity of the dredge and estuarine water temperatures. $B$. Variation of the flow at the dam and tide coefficients.

The low number of observations of the level of mortality did not enable a full testing of the effect of environmental variables (Figure 3) or fishing conditions on the level of mortality. The mean value of environmental conditions was calculated according to the mean residency duration in estuary calculated from pigment stages. For instance it was averaged on three days if the mean residency was three days. The correlation was analyzed between cumulated mortality rates and temperature, tide, flow, number of hour of dredging, fishing speed, fishing duration, level of catch. The influence of the fishing activity was analyzed according to the correlation between the percentage of injured glass eels and the total mortality.

\section{RESULTS}

\section{> EXPERIMENTAL USE OF INDIGO CARMINE TO DETECT MUCUS EROSION}

The glass eels wiped from their mucus presented various intensities of blue color on the skin and died quickly, while the untouched ones stayed alive and remained transparent when stocked in aquaria during two days (Table II). 


\section{Table II}

Table showing the differences in injury location between a sample of 21 glass eels which body has been wiped and a control sample of 20 glass eels. Results are expressed in percentage. $0=$ no mark, 1 = presence of a mark, 2 = marking visible on large areas.

\begin{tabular}{|c|c|c|c|}
\hline \multicolumn{2}{|c|}{ Injury localisation } & \multicolumn{2}{c|}{ Body wiped } \\
\hline Body & Tail & No & Yes \\
\hline $\mathbf{0}$ & 0 & 100 & 14.3 \\
\hline $\mathbf{1}$ & 2 & - & - \\
\hline & 0 & - & 38.1 \\
\hline $\mathbf{2}$ & 2 & - & - \\
\hline & 0 & - & 14.3 \\
\hline & 2 & - & 33.3 \\
\hline & & 100 & 100 \\
\hline
\end{tabular}

\section{> MORTALITY MONITORING}

\section{Samples collected during the fishing activity}

During the fishing period, the mortality recorded on board had a mean value of $2 \%$ ( $\min =0$, $\max =6.7 \%, N=10$ ). Back from the fishery, during the first sorting for dead glass eels, the mean initial mortality rate was $12 \%(\min =0, \max =36 \%, N=10)$. Combining the results of all replicates, the mean mortality after two days varied from 2 to $59 \%$ (mean $28 \%$ ). The mortality lessened after the first day (Table III) and the hourly rate of mortality passed from $1.23 \%$ for the first $24 \mathrm{~h}$ to $0.33 \%$ after one day and $0.08 \%$ after the second day. When we add to this value the initial mortality and the mortality recorded on board, the total mortality varies from 2 to $82 \%$ (mean 42\%).

\section{Samples collected with hand nets and at the trapping ladder}

The mortality after two days recorded from six samples fished with hand nets in the sluice is $0 \%$. One glass eel dropped from the net has been unfortunately stepped on while emptying the net during the fishery.

The mortality after two days from four samples collected at the trapping ladder is $0 \%$ even though some have escaped the aquaria and spent the night on the table.

\section{> ANALYSIS OF MUCUS EROSION}

A total of 2153 glass eels were examined individually under the stereo microscope, 1340 corresponding to glass eels collected during the fishing activity, 813 in the sluice. Dorsal and ventral injuries as body and tail injuries were dependent $(p<0.001)$. The dependence was also highly significant when looking at dead glass eels and living glass eels separately (Table IV). So the dorsal and ventral injuries were grouped as "body" injuries and analyzed for their relation to the tail injuries.

Among 1784 living glass eels, only $1(0.05 \%)$ was heavily injured (mark $=2)$ on the body, 120 $(7 \%)$ had injuries at the tail, and $230(13 \%)$ showed presence of a slight injury on the body (mark =1).

Among 369 dead glass eels, there was a low proportion of dead glass eels without marks on the tail $(6.7 \%, 25 / 369)$. Among the latter, the proportion of dead glass eels without marks on the tail with large body injuries (mark tail $=0$, body $=2,0.09 \%, 2 / 369$ ) differed significantly from the expected value indicating that glass eels injured on the body were almost always injured 
Table III

Mean mortality rates ( $<24 h, 24-48 h$ and $>48 h)$ for the 25 glass eel samples collected for the study.

\begin{tabular}{|l|c|c|c|c|}
\hline \multirow{2}{*}{ Date } & Type and number & \multicolumn{3}{|c|}{ Mean mortality rate } \\
\cline { 3 - 5 } & & $<24 \mathrm{~h}$ & $24-48 \mathrm{~h}$ & $>48 \mathrm{~h}$ \\
\hline $\mathbf{0 5 / 1 2 / 2 0 0 6}$ & push net (3) & 0.2 & 0.35 & 0.37 \\
\hline $\mathbf{0 7 / 1 2 / 2 0 0 6}$ & fishway (1) & 0 & 0 & 0 \\
\hline $\mathbf{0 8 / 1 2 / 2 0 0 6}$ & push net (2) & & 0.24 & 0.31 \\
\hline $\mathbf{1 2 / 1 2 / 2 0 0 6}$ & push net (3) & & 0.297 & 0.31 \\
\hline $\mathbf{1 3 / 1 2 / 2 0 0 6}$ & push net (3) & & & 0.19 \\
\hline $\mathbf{1 3 / 1 2 / 2 0 0 6}$ & fishway (1) & 0 & 0 & 0 \\
\hline $\mathbf{1 9 / 1 2 / 2 0 0 6}$ & push net (3) & 0.05 & 0.07 & 0.13 \\
\hline $\mathbf{2 1 / 1 2 / 2 0 0 6}$ & push net (3) & 0.01 & 0.13 & \\
\hline $\mathbf{0 8 / 0 1 / 2 0 0 7}$ & push net (3) & 0.39 & 0.48 & 0.51 \\
\hline $\mathbf{1 1 / 0 1 / 2 0 0 7}$ & push net (3) & 0.2 & 0.29 & \\
\hline $\mathbf{1 6 / 0 1 / 2 0 0 7}$ & push net (3) & 0.01 & 0.02 & 0.02 \\
\hline $\mathbf{2 3 / 0 1 / 2 0 0 7}$ & push net (3) & 0.03 & 0.08 & 0.08 \\
\hline $\mathbf{3 0 / 0 1 / 2 0 0 7}$ & push net (3) & 0.37 & 0.53 & 0.59 \\
\hline $\mathbf{0 6 / 0 2 / 2 0 0 7}$ & push net (3) & 0.04 & 0.07 & 0.14 \\
\hline $\mathbf{1 2 / 0 2 / 2 0 0 7}$ & push net (3) & 0.33 & 0.41 & 0.41 \\
\hline $\mathbf{2 0 / 0 2 / 2 0 0 7}$ & push net (3) & 0.15 & 0.28 & 0.32 \\
\hline $\mathbf{2 2 / 0 2 / 2 0 0 7}$ & push net (3) & 0.11 & 0.19 & 0 \\
\hline $\mathbf{0 5 / 0 3 / 2 0 0 7}$ & hand net (3) & 0 & 0 & 0 \\
\hline $\mathbf{1 6 / 0 3 / 2 0 0 7}$ & hand net (3) & 0 & 0 & 0 \\
\hline $\mathbf{2 2 / 0 3 / 2 0 0 7}$ & hand net (3) & 0 & 0 & 0.01 \\
\hline $\mathbf{2 6 / 0 3 / 2 0 0 7}$ & hand net (3) & 0 & 0 & 0 \\
\hline $\mathbf{0 3 / 0 4 / 2 0 0 7}$ & hand net (3) & 0 & 0 & 0 \\
\hline $\mathbf{1 0 / 0 4 / 2 0 0 7}$ & fishway (3) & 0 & 0 & 0 \\
\hline $\mathbf{1 7 / 0 4 / 2 0 0 7}$ & fishway (3) & 0 & 0 & 0 \\
\hline $\mathbf{1 8 / 0 4 / 2 0 0 7}$ & hand net (3) & 0 & 0 \\
\hline
\end{tabular}

on the tail (Table V). There was also a larger than expected proportion of glass eels that were found dead without any external injury (mark tail $=0$, body $=0, N=13,3.5 \%$ of dead glass eels, $0.7 \%$ of the total).

\section{> CORRELATION WITH ENVIRONMENTAL FACTORS}

The only significant correlation was found between total mortality and the percentage of injured glass eels (Spearman's rho $=0.76, p=0.04$ ). The other correlation was not significant with the largest correlation being with the number of glass eels caught (rho $=-0.52, p=0.12$ ), the mean speed (rho $=-0.41, p=0.26$ ) and the temperature (rho $=-0.4, p=0.24)$. Tide and flow had correlations lower than 0.3 . The mortality was not correlated with the number of hours of 


\section{Table IV}

Table showing the survival of 2153 glass eels according to the detection of injuries on the body in ventral and dorsal area. Results are expressed in percentage. The exponents correspond to values of standardized Pearson deviation from independence. Given the assumption of independence in the factors (normal distribution), * correspond to $p<0.05$, ${ }^{* *}$ to $p<0.0001,{ }^{(-)}$and ${ }^{(+)}$to a lower or higher percentage than expected.

\begin{tabular}{|c|c|c|c|}
\hline \multicolumn{2}{|c|}{ Mark intensity } & \multicolumn{2}{c|}{ Survival } \\
\hline Ventral & Dorsal & No & Yes \\
\hline $\mathbf{0}$ & 0 & $4.0^{(+)_{\star \star}}$ & $72.1^{(+) \star}$ \\
\hline & 1 & $1.3^{(-)_{\star}}$ & $1.4^{(-)_{\star \star}}$ \\
\hline $\mathbf{1}$ & 2 & $0.2^{(-)_{\star \star}}$ & - \\
\hline & 0 & $1.1^{(-)_{\star}}$ & $1.5^{(-) \star \star}$ \\
\hline & 1 & $4.4^{(+) \star *}$ & $7.8^{(+) \star \star}$ \\
\hline $\mathbf{2}$ & 2 & $0.7^{(-)_{\star}}$ & - \\
\hline & 0 & $0.4^{(-)_{\star \star}}$ & 0.0 \\
\hline & 1 & $1.2^{(-)_{\star}}$ & - \\
\hline & 2 & $3.7^{(+) \star \star}$ & 82.9 \\
\hline
\end{tabular}

\section{Table $V$}

Table showing the survival of 2153 glass eels according to the detection of injuries on the body and tail area.

\begin{tabular}{|c|c|c|c|}
\hline \multicolumn{2}{|c|}{ Injury localisation } & \multicolumn{2}{c|}{ Survival } \\
\hline Body & Tail & No & Yes \\
\hline $\mathbf{0}$ & 0 & $0.6^{(+) \star}$ & $71.2^{(+) \star}$ \\
\hline & 2 & 3.4 & $1.0^{(-) \star \star}$ \\
\hline $\mathbf{1}$ & 0 & 0.5 & $6.1^{(-) \star \star}$ \\
\hline $\mathbf{2}$ & 2 & 6.4 & $4.6^{(+) \star \star}$ \\
\hline & 0 & $0.1^{(-) \star}$ & - \\
\hline & 2 & 6.2 & 82.0 \\
\hline
\end{tabular}

dredging ( $r$ o $=0.27$ ) and this conclusion wasn't changed when using a constant duration of residency of 3 days instead of a calculation based on pigment stage structure.

\section{DISCUSSION}

The monitoring shows that glass eel fished for too long and at too high a speed die of mucus loss. This is clearly indicated by the following arguments: (1) It is shown using Indigo carmine that $97 \%$ of the dead glass eels have skin injury problems. The presence of large surfaces where the mucus has been removed on the body is almost always fatal, as indeed we only found one 
glass eel $(0.05 \%)$ having survived with large injuries on the body. So that leave $3.5 \%$ of the dead glass eels for which death might be due to other reasons than skin erosion (2) The only factor significantly correlated with mortality rate is the level of skin injury. (3) Samples collected with hand nets or at the trapping ladder do not die. Moreover, some glass eels collected at the trapping ladder escaped from the aquaria, but didn't die even if they spent the night out of water on the table.

The mucus forms an epithelial barrier responsible for osmotic integrity, and healthy glass eels are perfectly adapted to cope with salinity variations (Birrell et al., 2000; Wilson et al., 2004; Crean et al., 2007). When injured, the mucus coating looses transparency (Bocquéné and Miossec, 1986), the glass eel becomes atonic, and their inflated body reflects a massive influx of water into the body. In general, for fisheries, the abrasive quality of the netting material suggests that fish may sustain severe injuries during the tow, especially in the cod end where individuals are exhausted and crowded together (Suuronen, 2005). This might also be true for the glass eel as the nylon nets used to catch it are abrasive, though the absence of knots lessens this abrasive effect. In addition to the abrasion, at the landing, glass eels are wiped of a part of their mucus before calculating their weight, as they are expensive material. Given the high concentration of boats near the dam, with a number close to a hundred when the fishery is at its bulk, it is also possible that some glass eels are hurt by the engine screws.

The loss of mucus, and injuries at the tail, adds to the stress of towing and handling. The general stress increases oxygen consumption, and alters the osmotic ability through a cortisol release (McCormick, 2001). This factor therefore adds to the alteration of the mucus coating which is an important factor in both gas exchange and osmotic integrity (Tesch, 2003). For this reason the fish traders keep their glass eels in a hyper osmotic environment with large oxygen supplies shortly after having bought them, and some fishermen fill their tanks with salt water.

Our monitoring also clearly shows that mortality is linked with injury at the tail, as about three quarters of the fishes injured at the tail die in the two days after fishing, and less than $1 / 15$ of dead fishes aren't injured at the tail. In the extremity of the tail, a vascular system of ventricles and valves assists the blood circulation over the full length of the body (Tesch, 2003). Glass eels get caught at the outer opening of the net where the mesh size is generally 1.8 to $2 \mathrm{~mm}$. This kind of meshing sometimes leads to the rupture of the spine (Leroux and Guigues, 2002). Many glass eels get their tail meshed in the deepest part of the net where the mesh size is $1.3 \mathrm{~mm}$. This kind of injury, while considered as reversible (Monein-Langle, 1985) takes a large toll on the total mortality.

The injuries are also cause for a potential outbreak of diseases in the weakened glass eel. One of the two samples analyzed for disease during a mortality peak returned positive with an infection of Salmonella putrefaciens, Shewanella putrefaciens and Aeromonas sobria. These opportunistic bacteria, present in the aquatic environment, become pathogenic especially in the presence of fishes weakened by external stressors such as fishing activities. They might explain the highest mortality found in February in one of the samples. Disease causation is complex (Verthaak and Jol, 1996) and many factors interact to produce a spatial or temporal trend. The fishing causes an increase in stress, direct injury and abrasion of the mucus protective layer, which might contribute to the occurrence of a wave of infection in the fish trader tanks. A similar strong positive correlation between skin ulcers and the viral skin disease lymphocystis and the fishing activity was found in the Dutch Wadden Sea (Vethaak and Jol, 1996). The authors speculated that flounders, usually caught as a bycatch and discarded after fishery suffered wounds and damage of the protective mucus layer, and were subsequently more vulnerable to infectious pathogens.

Flooding periods are usually reported by fishermen and fish dealers as factors causing an increase in mortality. This was not apparent in this study as no factor external to the fishery could be statistically related to the level of mortality. Foremost, no relationship was found with the intensity of dredging, which is reduced in volume, and does not induce chemical contamination in mussels near the dredging site (IFREMER, unpublished results). Still, as most of the variations in mortality rates remain unexplained, a combination of factors from the environment such as 
increased silt loads, release of potential irritants by the dredge, low temperatures might also contribute to weaken the mucus coat and diminish the overall resistance of the glass eel.

Putting the glass eel in aquaria of estuarine water without extra care and oxygenation would stand as a poor practice for the fish dealers. So the results obtained there are probably not representative of the glass eel processing chain, which have lower mortality rates. Nonetheless, they might well represent the outcome of glass eel transport when directly putting back glass eels after fishing with tow nets.

One should also note that these results should not be regarded as representative of the whole Atlantic glass eel fishery. Mortality may vary from one estuary to the other as catch conditions, net shapes and dimensions, boat speed, fishing depth and haul duration also vary.

Fish dealers report that mortality is at its highest in the Vilaine (30 to $40 \%)$. Mortality recorded in the Loire would be around 15 to $20 \%$. A monitoring performed in the Loire in 2002 reports high fishing speed, between 1.16 to $3.4 \mathrm{~m} \cdot \mathrm{s}^{-1}$ (mean $2.26 \mathrm{~m} \cdot \mathrm{s}^{-1}$ ) when compared to those measured in the Vilaine $\left(1.4 \mathrm{~m} \cdot \mathrm{s}^{-1}\right)$. Mortality rates two days after fishing varied from 18 to $78 \%$. The mortality rates increased during the first $36 \mathrm{~h}$ then stabilized. The results showed a clear correlation between mortality and fishing speed, and a speed lower than $2.6 \mathrm{~m} \cdot \mathrm{s}^{-1}$ was recommended by the authors. A correlation between fishing duration and mortality rate was also identified on 7 samples. The fishing duration for a haul was 8 to $25 \mathrm{~min}$ according to the boat with a mean duration of $13 \mathrm{~min}$. For a same boat, an increase in mortality rate from 20 to $40-70 \%$ was observed as the fishing duration was increased from 5 to 25 min (Leroux and Guigues, 2002).

South from the Loire, in the Vendée, fishing conditions are close to those in the Vilaine, with most fishing concentrated at the bottom of dams, but mortality is only between 5 and $10 \%$ due to the use of fishing gear with a very long net end (Leroux and Guigues, 2002). In some smaller estuaries such as the Aulne in Brittany, the fishermen keep the glass eels in cages in the saline part of the estuary for several days before selling them. This practice helps them negotiate the price. While their nets are similar to those used in the Vilaine, the mortality is claimed to be much lower (5 to 10\%). Interestingly, we can directly compare these claims with the results from a similar experiment in the Aulne estuary from 1999 to 2001 (Briand, unpublished report). The boats speed was slightly higher than in the Vilaine (from $1.2 \mathrm{~m} \cdot \mathrm{s}^{-1}$ to $2.3 \mathrm{~m} \cdot \mathrm{s}^{-1}$ ) but with shorter tow duration. The mean total mortality rate was $36 \%$ ( $\min 0.5 \% \max 100 \%)$, comparable to that obtained in the Vilaine. The mortality also varied according to the position in the estuary, with larger mortality rates $49.6 \%$ (sd 30.9) in the downstream part of the estuary than in the upstream area at the tide reversal and accumulation area $(23.4 \%, \mathrm{sd} 21.5)$. The mortality was negatively correlated with the CPUE, indicating that dying glass eels were less fit for tidal stream transport, and this explains the large mortality $(100 \%)$ recorded in the downstream part of the estuary. The glass eels swimming at the surface were already losing their transparency and becoming white.

The mortalities in the Adour river (south of France) would also be of the magnitude of a few percent, and mortality around $30 \%$ is considered exceptional (Prouzet, pers. com.). The mortality would also be different for Pibalour, large nets used in the Gironde and Charente estuaries, but is not accounted to our knowledge in the literature.

In Ireland, some experiments resulting from the catch of glass eels at trapping ladders or using tela nets results in 0\% mortality (Crean et al., 2007).

To conclude, if the glass eel were to be transported throughout Europe, the mortality rate of the order of 20 to $40 \%$ induced by glass eel push net fisheries would probably not be compatible with the level of survival require restoring the eel stock in the long term. A large change in fishing practice would have to occur, ensuring shorter hauls, with a lower speed, to use glass eel fishing and transport from the Atlantic as a means to restore the stock. 


\section{ACKNOWLEDGEMENTS}

Frédéric Lefranc, professional fisherman for providing glass eels and his very welcome company during fishing trips. Jane Wilson for English corrections. This study was financed by the Institution d'Aménagement de la Vilaine, Agence de l'eau Loire Bretagne and the Bretagne region.

\section{REFERENCES}

Antunes C. and Weber M., 1996. The glass eel fishery and the by-catch in the Rio Minho after one decade (1981-1982 and 1991-1992). Archives of Polish Fisheries, 4, 131-139.

Birrell L., Cramb G. and Hazon N., 2000. Osmoregulation during the development of glass eels and elvers. J. Fish Biol., 56, 1450-1459.

Bocquéné G. and Miossec L., 1986. Toxicité aiguë et effets sublétaux, après une courte exposition de différents nonylphénols polyéthoxylés sur la civelle. Revue des Travaux de l'Institut des Pêches Maritimes, 48, 77-84.

Briand C., Fatin D. and Legault A., 2002. Role of odour on the efficiency of an eel, Anguilla anguilla, ladder and trap. Environ. Biol. Fish., 65, 473-477.

Briand C., Fatin D., Feunteun E. and Fontenelle G., 2003. Estuarine and fluvial recruitment of European glass eel in a fished Atlantic estuary. Fish. Manag. Ecol., 10, 377-384.

Briand C., Fatin D., Feunteun E. and Fontenelle G., 2005. Estimating the stock of glass eels in an estuary by mark-recapture experiments using vital dyes. Bull. Fr. Pêche Piscic., 378-379, 23-46.

Briand C., Bonhommeau S., Beaulaton L. and Castelnaud G., 2008. An appraisal of historical glass eel fisheries and markets: landings, trade routes and future prospect for management. In: Moriarty $\mathrm{C}$. (ed.), The Institute of Fisheries Management Annual Conference 2007, Wesport, Ireland.

Castelnaud G., Guérault D., Désaunay Y. and Elie P., 1994. Production et abondance de la civelle en France au début des années 90. Bull. Fr. Pêche Piscic., 335, 263-288.

Castelnaud G., Loste C. and Champion L., 2000. La pêche commerciale dans les eaux intérieures françaises à l'aube du XXlème siècle : bilan et perspectives. In: Symposium CECPI on fisheries and society, pp. 1-24, Budapest.

Commission of the European communities, 2005. Proposal for a Council regulation establishing measures for the recovery of the stock of European Eel., Rep. No. 472 final - 2005/0201 (CNS).

Crean S.R., Dick J.T.A., Evans D.W., Rosell R.S. and Elwood R.W., 2007. Survival of juvenile European eels (Anguilla anguilla), transferred among salinities, and developmental shifts in their salinity preference. J. Zool., 266, 11-14.

Elie P., 1979. Contribution à l'étude des montées de civelles d'Anguilla anguilla L. (poisson téléostéen anguilliforme) dans l'estuaire de la Loire : pêche, écologie, écophysiologie et élevage, thèse de $3^{\mathrm{e}}$ cycle, Université de Rennes, Rennes.

Elie P. and Fontenelle G., 1982. La pêche de la civelle Anguilla anguilla en France (Nécessité d'une gestion de cette ressource). Colloque International des entretiens écologiques de Dijon, pp. 112-124.

Friendly M., 1992. Mosaic Displays for Loglinear Models. ASA, Proceedings of the Statistical Graphics Section, Boston, pp. 61-68.

Gascuel D., 1985. Contribution à l'étude écologique des estuaires du littoral atlantique français : la faune accompagnatrice de la civelle, thèse de Docteur-Ingénieur, Université de Rennes I, Rennes.

Gascuel D., 1987. La civelle d'anguille dans l'estuaire de la Sèvre Niortaise : biologie, écologie, exploitation, rapport global. Publications Département Halieutique, École Nationale Supérieure Agronomique, Rennes.

Gisbert E. and López M.A., 2008. Impact of glass eel fishery on by-catch fish species: a quantitative assessment. In: Dufour S., Prévost E., Rochard E. and Williot P. (eds.), Fish and Diadromy in Europe. Hydrobiologia, 602.

ICES, 2008. Report of the Joint EIFAC/ICES Working Group on Eels (WGEEL), 3-9 September 2008, Leuven, Belgium, ICES CM 2008/ACOM:15, 212 p.

Leroux S. and Guigues T., 2002. Étude des facteurs et pratiques influençant la qualité de la civelle en Loire, Syndicat mixte pour le développement de l'aquaculture et de la pêche en pays de Loire/Association Agrée départementale des pêcheurs professionnels Maritimes et Fluviaux en eau douce de Loire Atlantique, Nantes. 
McCormick S.D., 2001. Endocrine control of osmoregulation in teleost fish. Amer. Zool., 41, 781-794.

Meyer D., Zeileis A. and Hornik K., 2006. The strucplot framework: Visualizing multi-way contingency tables with vcd. Journal of Statistical Software, 17, 1-48.

Monein-Langle D., 1985. Morphologie et physiologie digestive de la civelle d'Anguilla anguilla (Linnaeus, 1758 ) en phase préalimentaire dans les conditions naturelles et en régime thermique particulier, thèse de $3^{\mathrm{e}}$ cycle, Université de Perpignan, $143 \mathrm{p}$.

Robin J.P., 1990. By-catch of juvenile flounder, Platichthys flesus L. 1758, in the glass-eel fishery of the Loire Estuary, France. Aquat. Living Resour., 3, 75-83

Sobrino I., Baldo F., Garcia-Gonzales D., Cuesta J.A., Silva-Garcia A., Fernandez-Delgado C., Arias A.M., Rodrigez A. and Drake P., 2005. The effect of estuarines fisheries on juvenile fish observed within the Gadalquivir estuary (SW Spain). Fish. Res., 76, 229-242.

Suuronen P., 2005. Mortality of fish escaping trawl gears, Rome.

Tesch F.W., 2003. The eel. In: Thorpe J.E. (ed.), Blackwell Publishing, London, p. 407.

Vethaak A.D. and Jol J.G., 1996. Disease of flounder Platichthys flesus in Dutch coastal and estuarine waters, with particular reference to environmental stress factors. I Epizootiology of gross lesions. Dis. Aquat. Org., 26, 81-97.

Wilson J.M., Antunes C., Bouça P.D. and J.C., 2004. Osmoregulatory plasticity of the glass eel of Anguilla anguilla: freshwater entry and changes in branchial ion-transport protein expression. Can. J. Fish. Aquat. Sci., 61, 432-442. 